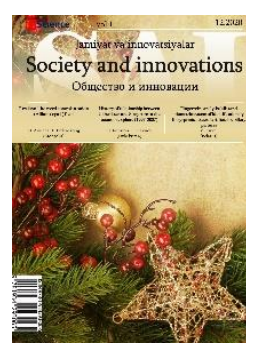

\title{
Some aspects of professional training of forensic experts for internal affairs bodies
}

\section{Lyudmila YUGAY ${ }^{1}$}

Academy of the Ministry of Internal Affairs of the Republic of Uzbekistan

\section{ARTICLE INFO}

Article history:

Received September 2020

Received in revised form

15 October 2020

Accepted 15 November 2020

Available online

31 December 2020

\section{Keywords:}

Forensic expertise activity

Legal

Professional training

Information technologies.

\begin{abstract}
This article is devoted to the issues of introduction of new approaches to training, retraining and advanced training of personnel for the forensic expertise departments of the internal affairs bodies. The normative legal acts of the Republic of Uzbekistan in training, retraining and advanced training of forensic experts are considered. The author analyzes the foreign experience and formulates proposals for improving the training of expert personnel for internal affairs bodies.

2181-1415/C) 2020 in Science LLC.

This is an open access article under the Attribution 4.0 International (CC BY 4.0) license (https://creativecommons.org/licenses/by/4.0/deed.ru)
\end{abstract}

\section{Ички ишлар органлари учун суд экспертларини тайёрлашнинг айрим жихатлари}

\section{Калит сўзлар:}

Эксперт-криминалистика фаолияти

Хукуқий

Касбий тайёргарлик

Ахборот технологиялари

\begin{abstract}
АННОТАЦИЯ
Ушбу мақола ички ишлар органларининг эксперткриминалистика бўлимлари учун кадрлар тайёрлаш, қайта тайёрлаш ва малакасини оширишда янги ёндашувларни жорий этиш масалаларига бағишланган. Ўзбекистон Республикасининг суд экспертларини тайёрлаш, қайта тайёрлаш ва малакасини ошириш сохасидаги нормативхуқуқий хужжатлари кўриб чиқилган. Муаллиф хорижий тажрибани тахлил қилган ва ички ишлар органлари учун мутахассис кадрлар тайёрлашни такомиллаштириш бўйича таклифлар берган.
\end{abstract}

\footnotetext{
${ }^{1} \mathrm{PhD}$, Academy of the Ministry of Internal Affairs of the Republic of Uzbekistan, Tashkent, Uzbekistan E-mail: yugay.lyudmila@inbox.uz
} 


\section{Некоторые аспекты профессиональной подготовки судебных экспертов для органов внутренних дел}

\author{
Ключевые слова: \\ Экспертно- \\ криминалистическая \\ деятельность \\ Правовая \\ Профессиональная \\ подготовка \\ Информационные \\ технологии
}

\begin{abstract}
АННОТАЦИЯ
Данная статья посвящена вопросам внедрения новых подходов к подготовке, переподготовке и повышению квалификации кадров для экспертно-криминалистических подразделений органов внутренних дел. Рассматриваются нормативно-правовые акты Республики Узбекистан в сфере подготовки, переподготовки и повышения квалификации судебно-экспертных кадров. Автором проводится анализ зарубежного опыта и формируются предложения по совершенствованию подготовки экспертных кадров для органов внутренних дел.
\end{abstract}

\section{INTRODUCTION}

One of the priority areas in development of law enforcement agencies is to increase the efficiency of forensic institutions, their scientific, technical, methodological base, in particular, forensic expertise departments of the internal affairs bodies.

The tasks of the forensic expertise departments of the internal affairs bodies include the organization and conduction of examinations and research, technical and forensic support of operational-search activities and investigative actions, the organization and maintenance of information, reference and forensic records, card files and collections, the organization and conduction of research work, experimental and design developments, their practical approbation, provision of conducting the expert research, etc. [1].

An analysis of the statistical indicators of the forensic expertise departments of the internal affairs bodies of the Republic of Uzbekistan for 2019 shows an increase in forensic examinations conducted by them in comparison with 2018 by $3.1 \%$, with a decrease in the total number of crimes for the indicated period of time by $6 \%$. At the same time, the total number of traditional forensic examinations in 2019 in relation to all conducted is $43.7 \%$. For 6 months of 2020, there is a decrease in the total number of forensic examinations compared to the same period in 2019 by $1.7 \%$, and the total number of traditional examinations for the specified period is $40.6 \%$ in relation to all forensic examinations [2].

The effectiveness of activities of the forensic expertise departments is directly proportional to the quality of training, retraining and advanced training of personnel in forensic activities.

I.E. Nikitina and E.V. Chesnokova note that the actualization of new criminal challenges throughout the world requires the activation and deepening of interaction between law enforcement agencies, including criminologists and forensic experts, the use of advanced forms of cooperation, where such a direction as training qualified personnel in the fight against crime comes to the fore, which is the most important direction of state activity of any country and contributes to the implementation of its law enforcement function [3, p. 74-76].

At the same time N.P. Mailis emphasizes that modern socio-economic conditions, the development of science and technology, changes in educational standards naturally entail higher requirements for the quality of training forensic experts. The solution to such a problem requires an integrated approach and depends on a number of factors [4, p. 12-15]. 


\section{MATERIALS AND METHODS}

Forensic divisions of the Republic of Uzbekistan carry out their activities in the Ministry of Internal Affairs, Ministry of Justice, Ministry of Health, Ministry of Defense, State Security Service and State Customs Committee. In accordance with the Resolution of the President of the Republic of Uzbekistan No. 4125 "On measures for further improving forensic activities" of January 17, 2019, non-state forensic organizations began to function in the Republic of Uzbekistan [5].

According to F.G. Aminev, in order to achieve a high level of forensic activity, not only the optimal organization of the activities of forensic expertise organizations, not only ensuring a continuous process of introducing modern scientific and technical means and methods, but also creating conditions for ensuring a high level of professional training of experts is necessary [6, p. 16-18].

In accordance with the Article 11 of the Law of the Republic of Uzbekistan No. LRU-249 "On forensic examination" of June 1, 2010, a person who is a citizen of the Republic of Uzbekistan and has a higher education, in exceptional cases - specialized secondary vocational education that has undergone compulsory training can be certified as a state forensic expert on a specific forensic specialty [7].

Certification as a state forensic expert is carried out on the basis of the Regulation on the procedure for holding attestation as a state forensic expert, approved by the Resolution of the Cabinet of Ministers No. 300 of December 16, 2010 [8].

The qualification of the state forensic expert is assigned in accordance with the list of expert specialties determined by the expert institution.

Based on the Resolution of the President of the Republic of Uzbekistan No. RP-3216 "On measures for radically improving the system of training, retraining and advanced training of employees of internal affairs bodies" of August 16, 2017, the Academy of the Ministry of Internal Affairs of the Republic of Uzbekistan is a higher specialized education institution for training, retraining and advanced training employees of internal affairs bodies.

Of course, the quality of training forensic experts through individual internships and short courses cannot be compared with the special education received in a specialized higher education institution.

Within the framework of the curricula of a higher education institution, it is envisaged to pass a complex of special disciplines, for each of which appropriate educational and work programs have been developed with an allotted amount of teaching hours, systematic control of the quality of mastering by students of the studied material. At the moment, specialists in forensic medicine and forensic psychiatry are trained in relevant medical higher education institutions, the Academy of the Ministry of Internal Affairs of the Republic of Uzbekistan graduates specialists in the direction of "Forensic expertise activity".

We agree with the opinion of N.P. Mailis, who believes that training of experts is carried out in different agencies and each of them has its own approaches to training. Differences in the organization and in teaching methodology do not contribute to the high-quality conduction of examinations, as well as the interaction of experts. Moreover, in the expert institutions of each system, there is a practice of training experts, which provides for the development of related specialties. Close interaction would be useful for developing common approaches not only in the process of training expert personnel, but also in conducting joint repeated and complex examinations [9, p. 56-59]. 
At the same time T.F. Moiseyeva notes that special training of forensic experts is possible within the framework of higher education in the specialty "Forensic examination" as an additional education to higher education in various branches of knowledge that are in demand for forensic expertise. At the same time, basic education can be obtained within the framework of a bachelor's degree, and additional education in forensic examination - in the form of professional retraining. Professional retraining in forensic examination and within the framework of the magistracy, which seems to be a more significant form, since it involves a more thorough (due to a longer training period of training forensic experts) is also possible. Additional education in forensic science should complement the existing knowledge in a particular area with knowledge of expert techniques, the main theoretical provisions of forensic examination, legal and organizational aspects. Additional education is not a second special education, but rather additional to the basic one [10, p. 160-168].

The Academy of the Ministry of Internal Affairs of the Republic of Uzbekistan trains specialists in traditional forensic examinations, who, upon graduation, receive a diploma of higher legal education and admittances to the right to produce these types of examinations. Graduates of the Academy, after passing the qualification exam in their specialty, receive the right to independently produce fingerprinting, traceological, ballistic, handwriting examinations, as well as technical and forensic examination of documents.

In connection with the planned introduction of amendments and additions to the criminal and administrative legislation related to the circulation and use of melee weapons, the issue of introducing teaching for the Academy cadets enrolled in the field of "Forensic expertise activity" of the educational discipline "Research of melee weapons" is being considered.

An important place in training the forensic expertise experts, along with obtaining deep theoretical knowledge, is development of practical skills necessary for the qualified execution of tasks assigned to the forensic expertise departments of the internal affairs bodies.

At the moment, the Academy of the Ministry of Internal Affairs of the Republic of Uzbekistan signed Memorandums of Cooperation with Tashkent State University of Law, the Republican Center for Forensic Expertise named after H. Suleymanova under the Ministry of Justice, the Main Forensic Center of the Ministry of Internal Affairs of the Republic of Uzbekistan, the Expert Criminalistics Center of the Main Department of Internal Affairs of the city of Tashkent. Practical classes in the specialty are conducted with the participation of leading scientists and specialists in various areas of forensic examination.

On the basis of the territorial divisions of the internal affairs bodies, seven branches of the Department of Forensic Examination function. In these branches of the department, field classes are held for cadets studying in the direction of "Forensic expertise activity", where in real conditions they have the opportunity to consolidate their practical skills.

Master classes and roundtable discussions with participation of foreign scientists and practitioners are systematically held, which make it possible to get acquainted with the advanced methods and means of conducting forensic examinations. The teaching staff of the Academy takes an active part in international workshops, conferences, foreign scientific internships.

Experts in various types of forensic examinations are also trained on the basis of the Institute for Advanced Studies of the Ministry of Internal Affairs. Based on the results of training, experts pass a qualifying exam to obtain the appropriate admission or confirmation. 
Certification of experts is a form of control over the required level of professional training and retraining of experts, the use of scientifically grounded modern methods and research techniques, modern technical means.

Qualification certification is an organizational measure, a procedure for granting a forensic expert and extending the right to independently conduct forensic examination for a specific type or expert specialty on the basis of checking the level of professional training of an employee, his knowledge of the organizational and legal foundations of forensic expertise activity, forensic examination methodology, knowledge of methods and techniques, skills and techniques for the production of forensic examination in a certain type of forensic examination or expert specialty, i.e. checking that he has special knowledge for the successful completion of expert work.

For certification as a state forensic expert at the Main Forensic Center of the Ministry of Internal Affairs of the Republic of Uzbekistan, an Expert Qualification Commission was created.

The Commission resolves issues:

- certification as a state forensic expert with the award of the right to independently produce a specific type of expert specialty;

- deprivation of the qualifications of a state forensic expert with the cancellation of the issued certificate of attestation as a state forensic expert (certificate), in the event of gross violations by him of the procedure for the production of forensic examinations determined by the head of the expert institution.

In accordance with the Article 11 of the Law of the Republic of Uzbekistan "On forensic examination", a state forensic expert can be a citizen of the Republic of Uzbekistan, with a higher, and in exceptional cases - a secondary specialized, vocational education, trained in a specific forensic expert specialty and passed certification.

It should be emphasized that T.V. Averyanova notes the need for a forensic expert to possess not only special knowledge, but also knowledge of the criminal procedural foundations. Especially during the period of permanent changes in the criminal procedure [11, p. 3-9].

We fully support this opinion, since forensic examination is regulated by the norms of procedural legislation (terms, grounds, procedure for appointment, etc.). The forensic expert must have knowledge of criminal procedures, be aware of criminal liability, etc.

According to A.I. Usov, international cooperation of leading forensic institutions and the potential of leading national and Eurasian universities will serve as the beginning of long-term and fruitful cooperation on the issues of modernization of professional training of forensic experts and formation of a system of continuous forensic education that is in great demand in the Eurasian Economic Union, its harmonization with the best international practice, innovative, scientific and educational technologies integrated into the quality management system of modern forensic laboratories. It is precisely in the modernization of forensic education that A.I. Usov sees a strategic solution to the problem of improving forensic support of legal proceedings and the rule of law in the EAEU member states [12, p. 20-25].

The advanced experience of Volgograd Academy of the Ministry of Internal Affairs of the Russian Federation, the East Siberian Institute of the Ministry of Internal Affairs of Russia, the Faculty of Law of Lobachevsky University, the Academy of the Ministry of Internal Affairs of the Republic of Belarus and many other education institutions shows the need for 
introducing new approaches in training specialists in the direction of "Forensic expertise activity" [13].

Analysis of foreign experience suggests that it is promising to create a separate Faculty for training forensic experts on the basis of the Academy of the Ministry of Internal Affairs of the Republic of Uzbekistan.

It is advisable to organize at the Faculty of forensic centers for identification of personality, thanks to which cadets in the learning process will be able to use the theoretical knowledge gained and practice practical skills in working with fingerprint and habitoscopic training databases, which at this time have the highest efficiency.

Further training of all state forensic experts, including internal affairs bodies, is carried out in accordance with the Resolution of the Cabinet of Ministers of the Republic of Uzbekistan No. 206 "On further improving the activities of the Republican Center for Forensic Expertise named after Kh. Suleymanova under the Ministry of Justice of the Republic of Uzbekistan, as well as organizing a system of improving the qualifications of forensic experts" of April 13, 2017 [14].

This Resolution provides for the improvement of legal and professional knowledge of all state forensic experts, regardless of departmental affiliation, every two years. All state forensic experts improve their legal knowledge exclusively at the Training Center for Advanced Training of Forensic Experts of the Republican Center for Forensic Expertise named after Kh. Suleymanova under the Ministry of Justice of the Republic of Uzbekistan on a reimbursable basis.

Forensic experts who have not undergone advanced training or legal knowledge are prohibited from engaging in forensic activities. This advanced training and legal knowledge is provided upon the expiration of two years of work experience for forensic experts as an expert.

Resolution of the President of the Republic of Uzbekistan No. RP-3216 "On measures for radically improving the system of training, retraining and advanced training of employees of internal affairs bodies" of August 16, 2017 [15], Resolution of the Cabinet of Ministers of the Republic of Uzbekistan No. 1052 "On measures for organizing the activities of the Institute of advanced training of the Ministry of Internal Affairs of the Republic of Uzbekistan" of December 27, 2018 [16], as well as departmental orders of the Ministry of Internal Affairs of the Republic of Uzbekistan determine the procedure for passing independent professional training of experts in forensic expertise departments of the internal affairs bodies.

A mentor with the relevant experience and work experience is assigned to the new forensic expertise departments employees, an individual plan is drawn up in accordance with the training program in this area of forensic examination. The mentor provides the traineeexpert with methodological and practical assistance in mastering theoretical material, acquiring practical work skills, provides comprehensive support and control over the implementation of the individual training plan, introduces to the production of examinations and research.

Upon completion of this training and successful passing of the qualification exam, the trainees-experts receive the so-called admission - a qualification certificate for the right to conduct examinations of this kind (type).

A.V. Kokin notes that the current system of state forensic organizations was formed in accordance with the needs of the executive authorities and is focused on solving the problems of individual departments, which absolutely does not contribute to the implementation of the 
principle of uniformity of expert practice. For a long time, expert services in different ministries have been developing independently, practically in isolation from each other. Many of them develop their own methodological support and independently train expert personnel. As a result, expert practice does not have a unified approach to solving some expert problems, and expert research methods of the same objects are different in nature [17, p. 22-30].

In addition, E.I. Galyashina believes that the actualization in modern conditions of the competence-based approach to the professional training of forensic experts determines the importance of unification and standardization of professional and qualification requirements for a forensic expert [18, p. 29-33].

Today, the achievements of IT technologies are being intensively introduced into forensic activities. Specialized databases, automated workplaces of forensic experts are being created, the "Electronic Criminal Case" project is being implemented, which allows to speed up document circulation process, to ensure transparency and appropriate control over the course of a criminal case investigation, and to receive forensic reports in electronic form, i.e. completely digitize the entire process of legal proceedings.

Automation of expert production consists in the use of technical means, mathematical methods and programs of activity, which partially or completely free the expert from direct participation in the process of receiving, transforming, transferring and using information in the production of expertise. In this regard, there is an urgent need for the implementation and functioning of automated information systems in forensic activities, contributing to an increase in the efficiency of search, collection, processing, storage, analysis, issuance and transmission of information. [4, p. 12-15]

The above-mentioned necessitates the training of expert personnel who have not only professional knowledge and practical skills, but also the ability to work with information technologies, to ensure the security of information of limited access.

\section{RESULTS AND ITS DISCUSSION}

Summing up, it should be noted that the system of training, retraining and advanced training of personnel of forensic expertise departments of the internal affairs bodies is one of the most important factors that determine the results of forensic expert activities and, accordingly, all justice, ensuring the rights and interests of citizens. The effectiveness of the entire judicial and legal system depends on the degree of professional competence of forensic experts. Within the framework of this article, it is not possible to consider all aspects of training of forensic experts for the internal affairs bodies.

Based on the above-mentioned, in order to increase the efficiency of training specialists for forensic expertise departments of the internal affairs bodies, we propose:

- to organize a specialized Faculty for training forensic experts at the Academy of the Ministry of Internal Affairs of the Republic of Uzbekistan, which would train specialists in all traditional types of forensic examinations;

- to ensure a systematic update of the advanced technical and forensic base at the Faculty for training specialists for forensic expertise departments of the internal affairs bodies;

- to introduce standardization of forensic expertise, certification of expert specialty, requirements for specialization, scientific and methodological approaches to similar forensic examinations, regardless of departmental affiliation. The above-mentioned will significantly 
improve the quality and efficiency of the system of training, retraining and advanced training of forensic experts;

- in addition to studying academic disciplines in the specialty "Forensic expertise activity", it is necessary to provide for an in-depth study of information systems, their principles of working with large volumes of information files, as well as information security requirements.

\section{CONCLUSIONS}

It should be noted that at the moment work is underway to address these aspects in training in the direction of forensic examination. Issues of training, retraining and advanced training of personnel for forensic departments cannot be resolved within one ministry or agency, since there is a need for coordinated efforts, the adoption of common expert methods, certification of specialties, improving legal knowledge, qualification requirements, etc.

\section{References}

1. On measures of radically improving the activities of the internal affairs bodies in crime investigation: Resolution of the President of the Republic of Uzbekistan, April 18. 2017, N RP-2898 / / Collection of Legislation of the Republic of Uzbekistan. - 2017. - No. 17. - Article 290.

2. Statistical indicators of the Main Forensic Center of the Ministry of Internal Affairs of the Republic of Uzbekistan.

3. Nikitina, I.E. Expert training as one of the ways to improve the efficiency of forensic expertise activity / I.E. Nikitina, E.V. Chesnokova // Bulletin of Moscow University of the Ministry of Internal Affairs of Russia. - 2017. - No. 2. - P. 74-76.

4. Mailis, N.P. Improvement of forensic expertise didactic activity with the use of innovative technologies / N.P. Mailis // Bulletin of the Academy of Economic Security of the Ministry of Internal Affairs of Russia. - 2015. - No. 2. - P. 12-15.

5. On measures for further improving forensic expertise activity [Electronic resource]: Resolution of the President of the Republic of Uzbekistan, 17 January 2019, No. 4125 // National database of legislation, January 19, 2019, No. 07/19/4125/2510. - T., 2019.

6. Aminev, F.G. On some problems of professional training of employees of forensic expertise departments of internal affairs bodies / F.G. Aminev // Bulletin of Moscow University of the Ministry of Internal Affairs of Russia. - 2016. - No. 5. - P. 16-18.

7. On forensic examination: Law of the Republic of Uzbekistan of June 1, 2010 No. LRU249 // Collection of Legislation of the Republic of Uzbekistan. - 2010. - No. 22. - Article 173.

8. On approval of the regulation on the procedure for attestation as a state forensic expert: Resolution of the Cabinet of Ministers of the Republic of Uzbekistan, December 16. 2010, No. 300 // Collection of Legislation of the Republic of Uzbekistan. - 2010. - No. 50. Article 475.

9. Mailis, N.P. On the need for enhancing the framework of the educational process in preparation of judicial experts / N.P. Mailis // Bulletin of Moscow University of the Ministry of Internal Affairs of Russia. - 2016. - No. 5. - P. 56-59.

10. Moiseyeva, T.F. Organizational and methodological aspects of training forensic experts / T.F. Moiseyeva / / Forensic Expert Examination. - 2019. - No. 2. - Volume 1. - P. 160168. 
11. Averyanova, A.V. Some problems of improving the professional training of students of higher education institutions of the Ministry of Internal Affairs / A.V. Averyanova // Bulletin of TSU. Economic and legal sciences. - 2014. - No. 4-2. - P. 3-9.

12. Usov, A.I. Modern training models of forensic experts as the basis for personnel provision of forensic expertise activity in the Eurasian Economic Union / A.I. Usov // Theory and practice of forensic examination. - 2015. - No. 4 (40). - P.20-25.

13. Training experts [Electronic resource]. - Access mode: https://xn--q1af2a.xn-p1ai/obuchenie-expertov/. - Date of access: 20.10.2020.

14. On further improvement of the activities of the Republican Center for Forensic Expertise named after Kh. Suleymanova under the Ministry of Justice of the Republic of Uzbekistan, as well as the organization of a system for advanced training of forensic experts: Resolution of the Cabinet of Ministers of the Republic of Uzbekistan, 13 April 2017, No. 206 // Collection of legislation of the Republic of Uzbekistan. - 2017. - No. 16. - Article 274.

15. On measures for radically improving the system of training, retraining and advanced training employees of internal affairs bodies: Resolution of the President of the Republic of Uzbekistan, August 16, 2017, No. RP-3216 // Collection of legislation of the Republic of Uzbekistan. - 2017. - No. 33. - Article 844.

16. On measures for organizing the activities of the Institute for Advanced Studies of the Ministry of Internal Affairs of the Republic of Uzbekistan: Resolution of the Cabinet of Ministers of the Republic of Uzbekistan, December 27, 2018, No. 1052 // National Database of Legislative Acts, 29.12.2018, No. 09/18/1052/2397.

17. Kokin, A.V. Problems of a unified scientific and methodological approach to expert practice, specialization of experts and their professional training / A.V. Kokin // Izvestiya TSU. Economic and legal sciences. - 2017. - No. 4-2. - P. 22-30.

18. Galyashina, E.I. Certification of expert specialties and professional education of forensic experts / E.I. Galyashina // Bulletin of Moscow University of the Ministry of Internal Affairs of Russia. - 2016. - No. 5. - P. 29-33. 